\title{
Efek aplikasi topikal gel ekstrak pandan wangi terhadap penyembuhan luka gingiva
}

\author{
Icha Nofikasari*, Afifah Rufaida*, Chynintia Dewi Aqmarina*, Failasofia*, Annisa Rahmi Fauzia**, Juni Handajani*** \\ *Pendidikan Dokter Gigi, Fakultas Kedokteran Gigi, Universitas Gadjah Mada, Yogyakarta, Indonesia \\ ${ }^{* *}$ Fakultas Farmasi, Universitas Gadjah Mada, Yogyakarta, Indonesia \\ ***Departemen Biologi Mulut, Fakultas Kedokteran Gigi, Universitas Gadjah Mada, Yogyakarta, Indonesia \\ *JI Denta No 1, Sekip Utara, Yogyakarta, Indonesia; e-mail: junihandajani@yahoo.com
}

Submisi: 3 Maret 2016; Penerimaan: 31 Maret 2016

\begin{abstract}
ABSTRAK
Luka pasca gingivektomi dibalut dengan periodontal dressing yang mengandung senyawa kimia dengan tujuan melindungi luka, namun senyawa kimia periodontal dressing yang ada di pasaran dapat menimbulkan efek alergi terhadap beberapa pasien. Daun pandan wangi (Pandanus amaryllifolius Roxb.) mengandung zat aktif yang memiliki anti inflamasi, antioksidan, dan antibakteri kemungkinan berperan dalam proses penyembuhan luka. Penelitian ini bertujuan untuk mengetahui peran gel ekstrak daun pandan wangi dalam proses penyembuhan luka pasca gingivektomi pada tikus wistar melalui pengamatan jumlah pembuluh darah. Model gingivektomi dilakukan pada gingiva incisivus mandibula dengan menggunakan punch biopsy diameter $2,5 \mathrm{~mm}$. Tiga puluh enam tikus dibagi secara acak ke dalam 3 kelompok perlakuan yaitu kontrol negatif (Gel CMC-Na), kontrol positif (Aloclair), dan gel ekstrak pandan wangi 50\%. Gel uji pada masingmasing kelompok diaplikasikan pada area luka pasca gingivektomi dua kali sehari. Pengamatan proses penyembuhan luka dilakukan pada hari ke 1, 3, 7, dan 14 dengan membuat preparat histologi gingiva area luka. Parameter penyembuhan luka yang diamati adalah jumlah pembuluh darah. Data jumlah pembuluh darah dianalisis dengan menggunakan uji statistik parametrik. Hasil penelitian menunjukkan jumlah pembuluh darah mengalami peningkatan mulai hari ke-3 dan mencapai puncaknya pada hari ke-7. Hasil uji two way Anova menunjukkan adanya perbedaan yang bermakna rerata jumlah pembuluh darah antar kelompok perlakuan dengan kontrol positif maupun negatif $(p<0,05)$. Hasil uji LSD juga menunjukkan perbedaan yang bermakna perbandingan kelompok kontrol dan perlakuan pada semua hari pengamatan. Kesimpulan penelitian ini adalah gel ekstrak pandan wangi $50 \%$ dapat mempercepat proses penyembuhan luka pasca gingivektomi dengan kemampuannya meningkatkan jumlah pembuluh darah.
\end{abstract}

Kata kunci: gingivektomi, pandan wangi, pembuluh darah, penyembuhan luka

\begin{abstract}
The Effect of topical application pandan extract gel on gingival wound. Post-gingivectomy wound is usually covered by periodontal dressing, which generally contains some chemical compounds to protect the wound. However, it can provide allergic effect on some patients. Pandan leaves (Pandanus amaryllifolius Roxb.) contain a number of active substances that have anti-inflammatory, antioxidant and antibacterial effect and play a role in wound healing. This study aims to determine the effect of topical application of Pandan leaf extract gel on gingival wound healing. Gingivectomy model was carried out on mandibular incisive gingival using the 2.5-mm punch biopsy. Thirty-six rats were randomly divided into 3 groups of treatment: negative control (CMC-Na), positive control (Aloclair), and 50\% of pandan extract gel. The gels on each group were applied (twice in a day) to the wound area after gingivectomy. The observation of the wound healing process was also carried out on day 1, 3, 7, and 14 by making the histological preparations of gingival wound area. The number of blood vessels was observed using microscope and data was analysed using TwoWay Anova and LSD. The result showed that number of blood vessel increased on day 3 and the peak was on day 7. Anova and LSD test showed several significant differences comparison the number blood vessel between treatment and control. In conclusion, topical application Pandan leaves extract gel could accelerate gingival wound healing.
\end{abstract}

Keywords: gingivectomy, pandan, blood vassels, woud healing

\section{PENDAHULUAN}

Gingiva merupakan bagian dari mukosa mulut yang mudah terkena luka. Luka pada gingiva dapat disebabkan oleh beberapa faktor, diantaranya adalah trauma, bahan kimia, dan bedah. ${ }^{1}$ Salah satu bedah gingiva yang sering dilakukan adalah gingivektomi. Gingivektomi merupakan pemo- tongan gingiva yang dilakukan pada penderita hiperplasi gingiva yang diakhiri dengan pemberian periodontal dressing untuk menutup luka yang dibuat pasca bedah. ${ }^{2}$

Luka merupakan rusaknya struktur anatomi dan terganggunya fungsi fisiologi tubuh. ${ }^{3}$ Adanya luka menimbulkan respon biologis berupa 
penyembuhan luka. Penyembuhan luka memiliki beberapa fase yaitu, fase hemostasis, fase inflamasi, fase proliferasi, dan fase remodeling. ${ }^{4}$ Tepat setelah perlukaan akan terjadi vasokonstriksi yang diikuti dengan vasodilatasi sehingga meningkatkan penyediaan darah di area luka. ${ }^{5}$ Selain itu, platelet akan mengalami degranulasi dan mensekresikan Platelet Derived Growth Factor (PDGF) untuk menarik sel leukosit polimorfonuklear (PMN) menuju daerah luka dan memulai fase inflamasi. Respon inflamasi berlangsung selama 4 hari yang didominasi oleh sel leukosit PMN dan makrofag. ${ }^{6}$ Setelah fase inflamasi akan terjadi fase proliferasi yang ditandai dengan pembentukan pembuluh darah baru dan sintesis kolagen. ${ }^{3}$ Angiogenesis atau pembentukan pembuluh darah baru merupakan kunci pada proses penyembuhan luka. Proses ini berperan memberikan suplai oksigen, nutrisi, sel inflamasi, dan menghilangkan jaringan yang mengalami nekrosis. ${ }^{7}$

Pandan wangi (Pandanus amaryllifolius Roxb) merupakan salah satu suku Pandanacea yang memiliki daun yang harum. ${ }^{8}$ Aroma harum dari daun pandan wangi membuat daun ini terkenal di masyarakat Asia Tenggara sebagai pemberi aroma pada makanan. ${ }^{9}$ Daun pandan wangi memiliki beberapa zat aktif yang diantaranya dapat membantu proses penyembuhan luka seperti flavonoid, saponin, dan tanin. ${ }^{10}$ Sampai saat ini penggunaan pandan wangi baru dilakukan secara empiris, sehingga manfaat pandan wangi belum sebagai bahan untuk mempercepat penyembuhan luka pada rongga mulut belum digali. Flavonoid dalam pandan wangi diduga memiliki fungsi sebagai antiinflamasi dan moderator sintesis kolagen tipe III, saponin berfungsi sebagai antibakteri dan dapat menstimulasi angiogenesis, sedangkan tanin berfungsi untuk membatasi infeksi sekunder. ${ }^{11,12}$ Penelitian ini bertujuan untuk mengetahui pengaruh ekstrak daun pandan wangi konsentrasi $50 \%$ dalam meningkatkan proses penyembuhan luka gingiva.

\section{METODE PENELITIAN}

Surat keterangan kelayakan etik diperoleh dari Komisi Etik Penelitian Fakultas Kedokteran Gigi, Universitas Gadjah Mada. Identifikasi daun pandan wangi dilakukan untuk memastikan bahwa tumbuhan yang digunakan dalam penelitian ini adalah benar daun pandan wangi (Pandanus amaryllifolius Roxb.). Identifikasi ini dilakukan di bagian Biologi Farmasi Fakultas Farmasi Universitas Gadjah Mada.

\section{Pembuatan Ekstrak Daun Pandan Wangi}

Pembuatan ekstrak daun pandan wangi dilakukan di Laboratorium Penelitian dan Pengujian Terpadu (LPPT) Unit III Universitas Gadjah Mada Yogyakarta. Pertama-tama daun pandan wangi dipotong-potong kecil dan dicuci bersih, lalu dikeringkan dalam almari pengering selama 48 jam dengan suhu $45{ }^{\circ} \mathrm{C}$. Daun pandan wangi yang telah kering dibuat serbuk menggunakan mesin penyerbuk. Proses berikutnya yaitu proses pembuatan ekstrak daun pandan wangi yang dilakukan dengan teknik maserasi, menggunakan pelarut etanol $96 \%$. Bubuk daun pandan wangi yang telah diperoleh kemudian ditambahkan etanol $96 \%$ diaduk dengan homogenizer selama 30 menit dan didiamkan 24 jam. Setelah 24 jam, campuran disaring menggunakan corong Buchner yang disertai dengan kertas saring. Perlakuan ini diulang sebanyak 3 kali hingga diperoleh hasil berupa ampas dan filtrat. Filtrat hasil penyaringan dijadikan satu lalu diuapkan dengan menggunakan vacuum rotary evaporation yang selanjutnya diuapkan kembali menggunakan pemanas water bath pada suhu $70{ }^{\circ} \mathrm{C}$ sehingga diperoleh ekstrak kental. Ekstrak tersebut kemudian dituang dalam cawan porselin lalu dipanaskan dengan water bath suhu $70^{\circ} \mathrm{C}$ sambil terus diaduk sehingga diperoleh ekstrak daun pandan wangi.

\section{Pembuatan Gel Ekstrak Daun Pandan Wangi}

Bahan CMC-Na ditimbang sebanyak 2 gram, kemudian ditambah $100 \mathrm{ml}$ akuades sehingga diperoleh konsentrasi $2 \%(\mathrm{~b} / \mathrm{v})$. Selanjutnya, untuk membuat gel ekstrak daun pandan wangi dengan konsentrasi $70 \%(\mathrm{v} / \mathrm{v})$ sebanyak $10 \mathrm{ml}$, dilakukan dengan memasukkan ekstrak sebanyak $7 \mathrm{ml}$ dalam larutan CMC-Na $2 \%$ sebanyak $3 \mathrm{ml}$ yang sudah dipanaskan dan diaduk selama 10 menit hingga merata, lalu dipindahkan dalam wadah dan didinginkan hingga menjadi gel. 


\section{Perlakuan pada Tikus}

Tikus Wistar sebanyak 36 ekor yang digunakan sebagai subjek penelitian diadaptasikan dalam kandang individual terlebih dahulu selama 3 hari. Tikus wistar kemudian dibagi secara acak menjadi 3 kelompok yaitu kelompok perlakuan 12 ekor, kelompok kontrol positif 12 ekor, dan kelompok kontrol negatif 12 ekor.

Sebelum diberi perlakuan, terlebih dahulu diinjeksikan ketamin $10 \mathrm{mg} / \mathrm{kg}$ BB secara intramuskular pada paha kanan atas tikus wistar untuk memberikan efek sedasi. Seluruh tikus kemudian diberi perlukaan menggunakan punch biopsy dengan diameter $2,5 \mathrm{~mm}$ pada gingiva labial mandibula tepat di bawah gigi incisivus sentralis. Pada kelompok perlakuan dioleskan gel ekstrak daun pandan wangi, kelompok kontrol positif dioleskan gel aloclair dan pada kelompok kontrol negatif dioleskan CMC-Na. Aplikasi gel dilakukan menggunakan micropipet sebanyak $0,05 \mathrm{ml}$ selama 1 menit, aplikasi dilakukan 2 kali sehari yaitu pada pagi dan sore.Pengorbanan akan dilakukan pada hari ke-1, 3, 7, dan 14 dengan masing-masing kelompok perlakuan diambil 3 ekor tikus secara acak untuk diambil jaringannya dan dibuat sediaan histologis. Tikus terlebih dahulu dianestesi dengan ketamin hingga overdosis, selanjutnya didekapitasi menggunakan gunting.

\section{Pembuatan Preparat Histologis}

Setelah dilakukan pengorbanan, rahang tikus diambil untuk dilakukan fiksasi pada larutan Buffered Natural Formalin (BNF) 10\% selama 24 jam, berfungsi sebagai bahan pengawet agar terhindar dari pencernaan jaringan oleh enzimenzim (otolisis) atau bakteri dan untuk melindungi struktur sel. Rahang tikus kemudian direndam dalam larutan dekalsifikasi yaitu larutan yang berfungsi untuk menghilangkan garam-garam kalsium dari jaringan tulang sebelum pemotongan sehingga tulang menjadi lunak, waktu perendaman selama 24 jam.

Prosedur dilanjutkan dengan fiksasi dan dekalsifikasi, jaringan lalu ditiriskan dengan saringan dan dipotong-potong menggunakan scalpe/ dengan ketebalan $0,3-0,5 \mathrm{~mm}$ dan disusun ke dalam tissue cassette, kemudian sejumlah tissue cassette dimasukkan ke dalam keranjang khusus. Keranjang yang di dalamnya berisi jaringan, dimasukkan ke dalam mesin processor otomatis. Selanjutnya jaringan mengalami proses dehidrasi bertahap dengan putaran waktu sebagai berikut: ethanol $70 \%$ (2 jam), ethanol $80 \%$ (2 jam), ethanol 90\% (2 jam), ethanol absolute (2 jam), ethanol absolute (2 jam). Tahap selanjutnya yaitu penjernihan dengan xylol (2 jam) sebanyak 2 kali.

Proses selanjutnya yaitu penghilangan udara dari jaringan menggunakan mesin vakum selama 30 menit, di dalammya terdapat tabung untuk menyimpan keranjang yang diisi parafin cair dengan temperatur $59-60{ }^{\circ} \mathrm{C}$. Keranjang diangkat, tissue cassette dikeluarkan dan disimpan pada temperatur $60{ }^{\circ} \mathrm{C}$ untuk sementara waktu sebelum pencetakan dilakukan dengan parafin cair. Cetakan dari bahan stainles steel dihangatkan di atas api Bunsen, ke dalam setiap cetakan dimasukkan jaringan sambil diatur dan sedikit ditekan. Di tempat lain telah disiapkan parafin cair dalam tempat khusus, sehingga dicapai suhu $60^{\circ} \mathrm{C}$. Parafin cair tersebut dituangkan ke dalam jaringan sampai seluruh jaringan terendam parafin. Parafin dibiarkan membeku di atas mesin pendingin. Selanjutnya blok parafin dilepas dari cetakan dan disimpan di freezer $\left(-20^{\circ} \mathrm{C}\right)$ sebelum dilakukan pemotongan.

Pemotongan blok parafin dilakukan menggunakan mesin mikrotom dengan ketebalan berkisar 3-4 $\mu \mathrm{m}$. Potongan tersebut diletakkan di atas permukaan air dalam waterbath bersuhu $46{ }^{\circ} \mathrm{C}$. Bentuk irisan dirapikan kemudian diletakkan di atas kaca obyek yang telah diolesi ewith, yang berfungsi sebagai perekat. Kaca obyek lalu disimpan dalam inkubator dengan suhu $2-5{ }^{\circ} \mathrm{C}$ di bawah titik lebur parafin sampai preparat siap diwarnai. Pewarnaan preparat untuk mengamati pembuluh darah menggunakan Hematoksilin Eosin.

\section{HASIL PENELITIAN}

Penelitian mengenai pengaruh aplikasi gel pandan wangi terhadap jumlah pembuluh darah pada proses penyembuhan luka pasca gingivektomi penelitian in vivo pada tikus Wistar menunjukkan peningkatan jumlah pembuluh 
darah. Hasil penelitian yang didapatkan berupa data berskala rasio yaitu perhitungan rerata dan simpang baku jumlah pembuluh darah pada setiap kelom pok perlakuan dan setiap hari pengamatan, dimuat pada Tabel 1 dan Gambar 1.

Tabel 1. Rerata dan simpang baku jumlah pembuluh darah

\begin{tabular}{cccc}
\hline $\begin{array}{c}\text { Hari } \\
\text { ke- }\end{array}$ & Kontrol Negatif & Kontrol Positif & Perlakuan \\
\hline 1 & $0,00 \pm 0,00$ & $3,00 \pm 1,00$ & $2,00 \pm 1,52$ \\
3 & $1,67 \pm 1,15$ & $5,33 \pm 2,30$ & $7,33 \pm 1,52$ \\
7 & $2,67 \pm 1,15$ & $4,67 \pm 0,50$ & $7,67 \pm 3,51$ \\
14 & $5,00 \pm 1,00$ & $2,33 \pm 1,52$ & $5,33 \pm 2,51$ \\
\hline
\end{tabular}

Keterangan:

Kontrol Negatif : aplikasi CMC-Na 2\%

Kontrol Positif : aplikasi gel Aloclair ${ }^{\mathrm{TM}}$

Perlakuan : aplikasi gel pandan wangi konsentrasi $50 \%$
Hasil penelitian menunjukkan rerata jumlah pembuluh darah pada tiap kelompok perlakuan dan hari pengamatan (Tabel 1 dan Gambar 1). Jumlah pembuluh darah pada kelompok perlakuan gel pandan wangi $50 \%$ lebih banyak daripada kelompok kontrol positif dan kontrol negatif ditiap hari pengamatan.

Hasil uji statistik Two-way ANOVA menunjukkan adanya perbedaan yang bermakna rerata jumlah pembuluh darah pada kelompok kontrol positif, kontrol negatif, dan perlakuan gel pandan wangi $50 \%$ di tiap hari pengamatan dengan nilai $p=0,000(p<0,05)$. Hasil tersebut menunjukkan ada pengaruh pemberian CMC-Na 2\% (Kontrol negatif), gel Aloclair ${ }^{\mathrm{TM}}$ (Kontrol positif), dan gel pandan wangi $50 \%$ (perlakuan) terhadap jumlah pembuluh darah pada area luka gingiva pasca gingivektomi. Selain itu, juga terdapat pengaruh hari pengamatan

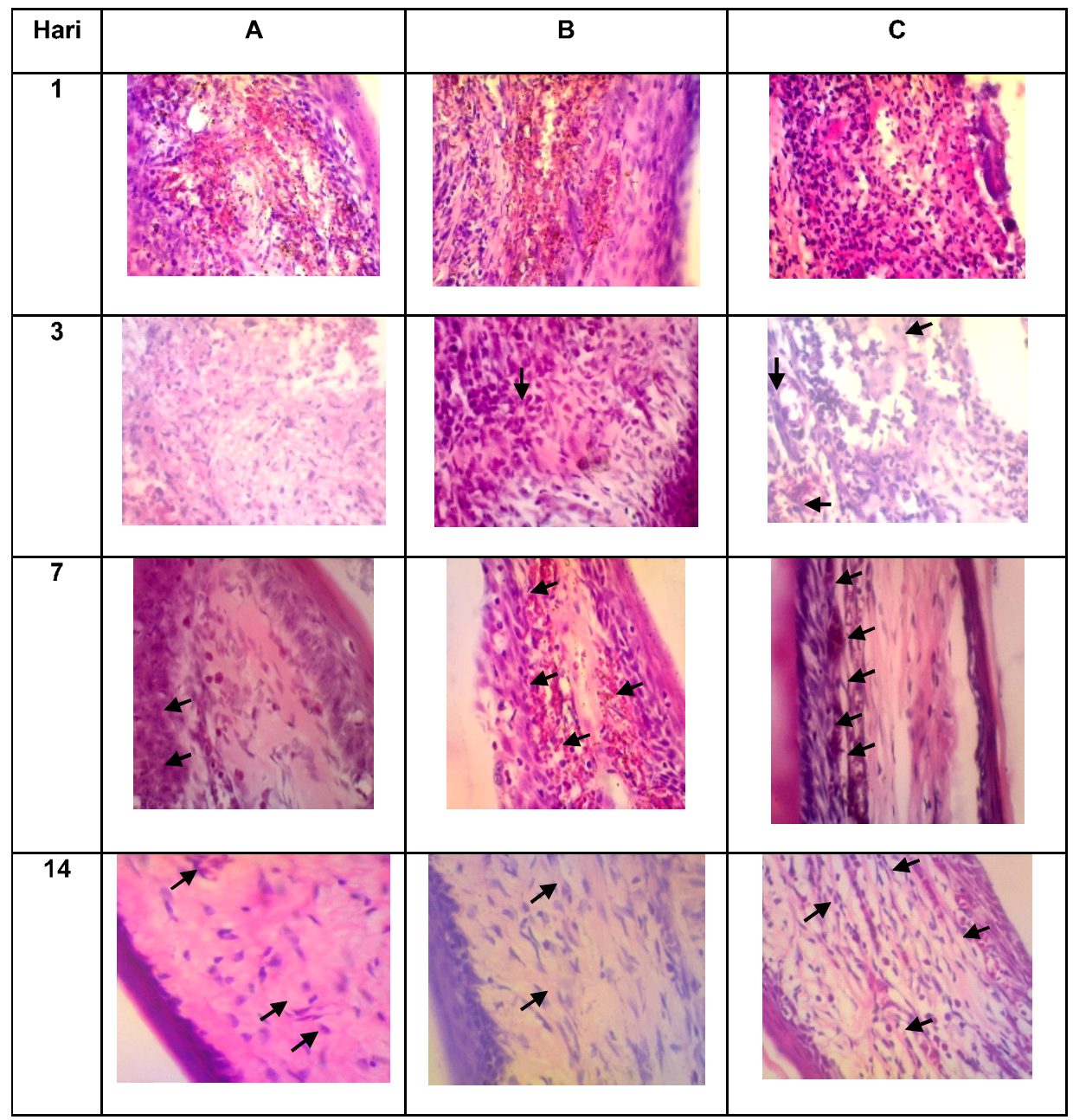

Gambar 1. Preparat histologis gingiva mandibula tikus hari ke-1,3,7, dan 14 dengan param eter jumlah pembuluh (tanda panah) darah grup kontrol negatif, (B) grup kontrol positif dan (C) grup perlakuan 
terhadap jumlah pembuluh darah pada area luka gingiva pasca gingivektomi. Hasil uji Post-hoc menunjukkan adanya perbedaan rerata jumlah pembuluh darah antara kelompok perlakuan gel pandan wangi $50 \%$ dengan kelompok kontrol positif dan kontrol negatif $(p<0,05)$.

\section{PEMBAHASAN}

Penyembuhan luka merupakan suatu respon biologis apabila tubuh mengalami perlukaan. Proses penyembuhan luka pada gingiva merupakan salah satu contoh penyembuhan luka pada rongga mulut. Umumnya proses penyembuhan luka diamati secara in vivo dengan menggunakan hewan coba. Pada penelitian ini digunakan hewan coba berupa tikus Wistar yang diberi perlukaan eksisi dengan menggunakan punch biopsy berdiameter $2,5 \mathrm{~mm}$ pada jaringan gingiva mandibulanya. Luka eksisi merupakan jenis luka sekunder yang mampu menunjukkan perubahan perbaikan jaringan secara jelas. Secara umum penyembuhan luka terdiri dari empat fase yaitu, fase hemostasis, fase inflamasi, fese proliferasi, dan fase remodelling. Peran ekstrak daun pandan wangi pada proses penyembuhan luka adalah pada fase akhir inflamasi dan fase proliferasi. $3,13,4$

Parameter keberhasilan proses penyembuhan luka bervariasi, salah satunya adalah pembentukan pembuluh darah baru. ${ }^{14}$ Pembuluh darah baru yang terbentuk akan mensuplai oksigen dan nutrisi sehingga sel terhindar dari kematian. Pembentukan pembuluh darah baru juga bertujuan untuk meningkatkan permeabilitas vaskular, meningkatkan proliferasi dari sel endotel, meningkatkan mitosis dari sel endotel, mengatur migrasi sel endotel, pembentukan lumen pembuluh darah yang baru, kemotaksis dari makrofag, dan vasodilatasi. ${ }^{7,15}$

Pembentukanpembuluhdarahbarumerupakan suatu proses penting dalam penyembuhan luka yang melibatkan faktor pertumbuhan terutama PDGF, VEGF dan bFGF, serta sel progenitor endotel. ${ }^{16}$ Pembentukan pembuluh darah baru dimulai dengan degradasi pembuluh darah lama dengan menyediakan pembentukan sel progenitor pembuluh darah. Sel progenitor pembuluh darah tersebut kemudian migrasi ke arah distal dari pembuluh darah kapiler semula untuk menstimulasi angiogenik. ${ }^{17}$ Migrasi sel progenitor pembuluh darah baru ini dipengaruhi oleh VEGF yang dikeluarkan sel makrofag saat pembuluh darah mengalami kerusakan dan hipoksia. Produksi VEGF juga diregulasi oleh faktor pertumbuhan lain seperti TGF- $\beta$ dan PDGF. Menurut teori, produksi VEGF dan aktivitas VEGF yang berperan dalam angiogenesis meningkat pada fase awal luka yang mengalami hipoksia, kemudian mengalami penurunan setelah neovaskularisasi telah komplit serta perfusi di area luka telah kembali norma. Selain VEGF, FGF menginisiasi angiogenesis ketika terjadi kerusakan diarea luka, FGF akan segera dilepas dan mempengaruhi sel-sel lain. Banyak sel yang memiliki reseptor FGF maka FGF yang terlarut menstimulasi beberapa proses seperti proliferasi dan migrasi sel endothelial. ${ }^{18}$ Proses proliferasi sel endotel diawali dengan pembentukan lumen (kanalisasi) melalui mekanisme intrasel dan intersel termasuk pengerahan dan proliferasi dari perisit (untuk pembuluh darah) serta otot polos (untuk pembuluh darah besar) untuk mendukung dinding endotel dan menyediakan fungsi tambahan, anastomosis dengan sel progenitor endotel lainnya dan pembentukan simpul, perkembangan sirkulasi dan penyesuaian saluran-saluran dengan segmensegmen arteri dan vena. ${ }^{17}$

Berdasarkan hasil pengamatan pada hari ke1, jumlah rerata pembuluh darah yang terbentuk belum banyak, hal tersebut karena proses pembentukan pembuluh darah yang baru belum terjadi, sehingga pembuluh darah yang terlihat pada preparat merupakan pembuluh darah lama.

Pada hari ke-3 jumlah rerata pembuluh darah yang terlihat pada preparat histologis lebih banyak dibandingkan pada hari ke-1 karena pada saat itu kuncup pembuluh darah atau sel progenitor endotel menuju sirkulasi darah ke jaringan granulasi untuk menjadi endotel matur yang akan memulai angiogenesis. Hasil pengamatan pada hari ke-7 menunjukkan jumlah rerata pembuluh darah yang paling banyak karena sel endotel mengalami puncak proliferasi. 
Pada hari ke-14 pembuluh darah yang terbentuk mulai stabil dan berkurang jumlahnya karena matriks ekstraselular mulai mengisi daerah yang hilang karena perlukaan, selain itu penurunan aktivitas VEGF juga mempengaruhi penurunan jumlah rerata pembuluh darah. ${ }^{19,16}$ Jumlah pembuluh darah antara kelompok gel pandan wangi $50 \%$ dengan kelompok kontrol positif maupun negatif menunjukkan ada perbedaan. Hal tersebut disebabkan flavonoid yang mampu mengatur fungsi sel inflamasi dengan cara merangsang produksi TGF- $\beta$ yang merupakan kemoatraktan spesifik untuk menstimulasi makrofag dan bFGF yang mampu menimbulkan pembentukan pembuluh darah baru juga berpartisipasi dalam meningkatkan migrasi dan proliferasi sel makrofag, fibroblast, dan endotel di area luka serta menginduksi VEGF yang berperan dalam proses pembentukan pembuluh darah baru. Keberadaan saponin dalam daun pandan juga berpengaruh terhadap upaya pencegahan perusakan jaringan termasuk pembuluh darah oleh bakteri maupun produknya yang dapat menstimulasi respons inflamasi. ${ }^{20,21}$

\section{KESIMPULAN}

Gel pandan wangi konsentrasi $50 \%$ dapat meningkatkan vaskularisasi pada fase proliferasi proses penembuhan luka gingiva.

\section{UCAPAN TERIMAKASIH}

Peneliti mengucapkan terimakasih kepada Departemen Pendidikan dan Kebudayaan Republik Indonesia melalui Program Kreativitas Mahasiswa - Penelitian (PKM-P) tahun 2015 yang telah membiayai penelitian ini.

\section{DAFTAR PUSTAKA}

1. Solanki G. A general overview of gingiva. IJBR. 2012; 3(02): 79 - 82.

2. Carranza F, Newman M, Takei H. Carranza's clinical periodontology $10^{\text {th }}$ ed. Philadelphia: W.B. Saunders Company; 2006. $26-27$.
3. Andreasen J, Andreasen F, Andersson L. Textbook and color atlas of traumatic injuries to the teeth $4^{\text {the }}$ ed. Denmark: Blackwell Munksgaard; 2007. 3 - 16.

4. Masir O, Manjas M, Putra AE, Agus S. Pengaruh cairan Cultur Filtrate Fibroblast (CFF) terhadap penyembuhan luka; penelitian eksperimental pada rattus norvegicus galur wistar. JKA. 2012; 1(3): 112 - 117.

5. Velnar T, Bailey T, Smrkolj V. The wound healing process: an overview of the cellular and molecular mechanisms. J Int Med Res. 2009; 37(5): 1528 - 1542.

6. Wehrhan F, Schutze-Mosgau S, Schliephake $\mathrm{H}$. Salient features of the oral mucosa, in Hom D, Hebda P, Goswami A, Friedman C (ed.): Essential Tissue Healing of the Face \& Neck, PMPH, USA: 2009. 83 - 95.

7. Figg WD, Folkman J. Angiogenesis an integrative approach from scirnce to medicine. USA: Springer Science Business Media LLC; 2008. 536.

8. Hidayat $S$, Wahyuni $S$, Andalusia S. Seri tumbuhan obat berpotensi hias. Jakarta: Elex Media Komputindo; 2008. 71 - 73.

9. Hariana A. Tumbuhan obat dan khasiatnya. $2^{\text {nd }}$ ed. Jakarta: Penebar Swadaya; 2008. 164.

10. Margareta S, Handayani SD, Indraswati N, Hindarso H. Ekstraksi Senyawa Phenolic Pandanus Amaryllifolius Roxb. sebagai Antioksidan Alami. Widya Teknik. 2011; 10(1): $21-30$.

11. Lafuente AG, Guillamon E, Villares A, Rostagno MA, dan Martinez JA. Flavonoid as antiinflamatory agents: implication in cancer and cardiovaskular disease. Inflam Res. 2009; 58: $537-552$.

12. Dumaoal OSR, Alaras LD, Sarah KGD, Depadua AA, Pulmones CJG. In vitro activity of pandan (Pandanus amaryllifolius) leaves crude extract against selected bacterial isolates. JPAIR. 2010; 4: $103-124$. 
13. Ferdinandez $K$, Dada $A$, Damriyasa IM. Bioaktivitas ekstrak daun tapak dara (Catharantus roseus) terhadap kecepatan angiogenesis dalam proses penyembuhan luka pada tikus wistar. Indonesia Medicus Veterinus. 2013; 2(2): $180-190$.

14. Mustafida RY, Munawir A, Dewi R. Efek antiangiogenik ekstrak etanol buah mahkota dewa (Phaleria macrocarpa (Scheff.) Boerl.) pada Membran Korio Alantois (CAM) Embrio Ayam. E-Jurnal Pustaka Kesehatan. 2014; 2(1): $4-8$.

15. Sabirin IPR, Maskoen M, Hernowo BS. Peran ekstrak etanol topikal daun mengkudu (Morinda citrifolia L.) pada penyembuhan luka ditinjau dari imunoekspresi CD34 dan Kolagen pada tikus galur wistar. MKB. 2014; 45(4): 226 $-233$.

16. Esimone C, Nworu, Jackson CC. Cutaneous wound healing activity of a herbal ointment containing the leaf extract of Jatropha Curcas L. (Euphorbiaceae). Int Appl Res Nat Project. 2008; 1(4): $1-4$.
17. Granick MS, Gamelli RL. Surgical wound healing and management. New York: Informa; 2007. $45-51$.

18. Kalangi SJR. Peran integrin pada angiogenesis penyembuhan luka. CDK. 2011; 38(3): 177 181.

19. Frisca, Sardjono CT, Sandra F. Angiogenesis: patofisiologi dan aplikasi klinis. JKM. 2009; 8(2): $174-187$.

20. Riana AR. Peran Heparin dalam angiogenesis, epitelisasi, dan penyembuhan luka bakar. Staff pengajar Lab. IImu Bedah Fakultas Kedokteran Universitas Muhammadiyah Malang. 2011; 7(14): 26 - 32.

21. Athiroh ASN, Permatasari N. Mekanisme kerja benalu teh pada pembuluh darah. Jurnal Kedokteran Brawijaya. 2012; 27(1): 1 - 7. 